- FINANSE I PRAWO FINANSO WE.

- Journal of Finance and Financial Law $•$

Marzec/March 2018 • vol. 1(17): 79-96

https://doi.org/10.18778/2391-6478.1.17.07

\title{
REKLAMA BANKOWA JAKO NARZĘDZIE AKTYWNOŚCI PROMOCYJNEJ INSTYTUCJI FINANSOWYCH
}

\author{
Weronika Seta, Karolina Wrońska, Szymon Cegiełko ${ }^{1}$ \\ Wydział Ekonomiczno-Socjologiczny \\ Uniwersytet Łódzki
}

\section{Streszczenie}

Wymagający klienci oraz szeroki zakres proponowanych przez instytucje finansowe produktów i usług tworzy barierę swobodnego wejścia tychże instytucji na rynek finansowy. Oferowanie zbliżonych produktów różniących się jedynie nazwą nie wyróżnia w żaden sposób danej jednostki od konkurencji, dlatego też tak ważną rolę odgrywa marketing - reklama. W oparciu o analizę wybranych przez autorów banków i działań marketingowych, które podejmują, przedstawiono czym jest reklama i jak wpływa na ich poczynania, a także na potencjalnych klientów. W artykule wykazano zależność między wydatkami na reklamę a sytuacją finansową danej instytucji, w oparciu o dane wybranych jednostek, które odznaczyły się aktywnością na rynku bankowym.

Słowa kluczowe: reklama, marketing bankowy, wizerunek, instytucja finansowa.

JEL Class: M31, M37, G21.

\footnotetext{
${ }^{1}$ Autorzy pragną podziękować dr hab. I.D. Czechowskiej, prof. nadzw. UŁ za wsparcie i pomoc merytoryczną.
} 


\section{WPROWADZENIE}

Produkty i usługi bankowe, podobnie jak każde inne sprzedawane towary, wymagają reklamy. W literaturze przedmiotu znajdziemy opis szeroko rozumianej terminologii, pozwalającej wyjaśnić czym jest i jakie korzyści niesie ze sobą promowanie sprzedawanych przez przedsiębiorstwo wyrobów oraz świadczonych usług. Spośród wielu definicji istotne jest wyjaśnienie tego pojęcia, które zawarte jest $\mathrm{w}$ regulacjach prawnych. Powołując się na jeden $\mathrm{z}$ aktów prawnych regulujących tę problematykę można wskazać, że reklama to ,przekaz handlowy, pochodzący od podmiotu publicznego lub prywatnego, w związku z jego działalnością gospodarczą lub zawodową, zmierzający do promocji sprzedaży lub odpłatnego korzystania z towarów lub usług" [Ustawa z dnia 29 grudnia 1992 r...., art. 4, Dz.U. 2017, poz. 1414, ze zm].

Reklama stanowi jedno $\mathrm{z}$ wielu narzędzi marketingu. W XXI w. marketing odgrywa znaczącą rolę $\mathrm{w}$ społeczeństwie, a promowanie produktów jest niezbędnym elementem działań wszystkich instytucji, których celem jest osiągnięcie sukcesu na rynku. Ze względu na różnorodność reklam bankowych, mnogość kanałów dystrybucji reklam, a także skutków jakie niesie ze sobą przekaz, autorzy pracy postanowili zbadać zagadnienie reklam bankowych jako narzędzi promocji instytucji finansowych.

Celem artykułu jest przedstawienie i ocena funkcjonowania reklamy bankowej. Autorzy opracowania będą poszukiwać odpowiedzi na pytanie badawcze, dotyczące zależności pomiędzy wydatkami na reklamę a sytuacją finansową instytucji bankowych, a także podejmą próbę ustalenia wpływu, jaki wywierają reklamy bankowe na odbiorców.

Temat opracowania reklam jako narzędzi promocyjnych instytucji finansowych został przedstawiony w podziale na dwie zasadnicze części: jedna ma charakter teoretyczny, a druga empiryczny. W części teoretycznej zawarto opis specyfiki reklamy w perspektywie działań promocyjnych stanowiących element marketingu. W tej części ukazano elementy genezy, aspekty prawne, cele i zasady dotyczące funkcjonowania reklam, główne idee zastosowań promocji w sektorze bankowym oraz zastrzeżenia w aspektach prawnych. Natomiast w części empirycznej zaprezentowano przykłady reklam na rynku bankowym, analizę głównych kosztów oraz wyszczególnienie grupy docelowej zastosowanych działań marketingowych. 


\section{TEORETYCZNY ASPEKT FUNKCJONOWANIA REKLAMY}

Rozwój technologii oraz upowszechnienie się sieci internetowej w społeczeństwie wymusiły na instytucjach finansowych zmiany w zakresie komunikacji z potencjalnymi klientami. Dotychczas wszelkie sprawy bankowe rozstrzygane były w spotkaniach bezpośrednich, a sam użytkownik usług finansowych musiał udać się do siedziby instytucji, z którą podejmował współpracę. Wraz z rozwojem marketingu elektronicznego zmieniły się także formy kontaktu z klientami - co dziś możemy rozumieć jako marketing bankowy. Współcześnie instytucje finansowe skupiają się na długofalowych działaniach marketingowych. Najważniejszą rolę w bankowości uzyskały działy technologii informatycznej, a pracownicy szkoleni są w taki sposób, by tworzyć odpowiednią atmosferę zarówno wewnątrz, jak i na zewnątrz środowiska przedsiębiorstwa [Zespół wfirma.pl, 09.06.2017, dostęp: 30.12.2017]. Sama reklama natomiast stała się częścią kompleksowej koncepcji marketingu.

\subsection{Cele reklamy finansowej}

Zastosowanie reklamy na rynku finansowym związane jest z trzema głównymi czynnościami. Na podstawie rozważań Krystyny Mazurek-Łopacińskiej cele realizowane w ramach reklamy finansowej można przedstawić jako: informujące, nakłaniające, przypominające (zob. tab. 1).

Tabela 1. Działania podejmowane przez instytucje bankowe ze względu na wybór określonego celu reklamy

\begin{tabular}{|c|c|}
\hline Cel reklamy finansowej & $\begin{array}{l}\text { Podejmowanie działania w zakresie określonego } \\
\text { celu reklamy finansowej }\end{array}$ \\
\hline Informowanie & $\begin{array}{l}\text { - rynek zostaje poinformowany o nowym produkcie } \\
\text { - informowanie o cenach oraz świadczonych usługach } \\
\text { - wyjaśnianie obsługi produktu } \\
\text { - tworzenie wizerunku } \\
\text { - zmniejszanie obaw klienta } \\
\text { - sugerowanie nowych zastosowań }\end{array}$ \\
\hline Nakłanianie & $\begin{array}{l}\text { - budowanie świadomości marki } \\
\text { - zachęcanie do zmiany marki } \\
\text { - nakłanianie konsumenta do zakupu lub złożenia zamówienia }\end{array}$ \\
\hline Przypominanie & $\begin{array}{l}\text { - przypominanie o wadze skorzystania z produktu } \\
\text { - przypominanie o możliwości nabycia produktu i dostępności miejsc } \\
\text { - utrzymywanie wcześniej zdobytej wiedzy o produkcie } \\
\text { - przypominanie o istnieniu produktu. }\end{array}$ \\
\hline
\end{tabular}

Źródło: opracowanie własne na podstawie: Mazurek-Łopacińska [1997: 72]. 
Wszystkie instytucje finansowe korzystające z reklam jako elementu strategii marketingowej mają na uwadze reagowanie na trendy oraz zmiany. Stworzenie nowego produktu bankowego wiąże się z tym samym cyklem działań połączonym z życiem danej innowacji. Najpierw wprowadza się go na rynek, tym samym tworzy wizerunek firmy oraz zapoznaje potencjalnych klientów z nowościami - jest to pierwszy możliwy cel reklamy, określa się go jako informacyjny. Następnie pojawia się faza wzrostu sprzedaży produktów. Wtedy też przedsiębiorstwo nakłania konsumenta do zakupu danej nowości oraz następuje budowanie świadomości marki - wszelkie te działania możemy skojarzyć z kolejnym z celów reklamy finansowej - nakłanianiem. Trzeci etap życia produktu to dojrzałość związana ze stabilizacją wolumenu sprzedaży. W tym etapie, jak i następnym - czyli schyłku, reklamy mają za cel przypominać klientom o produkcie oraz o marce [Witek-Hajduk: 182, dostęp: 03.01.2018].

W odniesieniu do sytuacji instytucji finansowej można dokonać bardziej skrupulatnego podziału działań związanych z reklamą bankową i próbami dotarcia do klientów. Banki na różnym etapie rozwoju swojej działalności będą wybierać inne czynności, których głównym celem będzie zwiększanie liczby osób korzystających z usług oraz poprawienie pozycji na rynku finansowym.

Tabela 2. Cele reklamy finansowej ze względu na aktualną sytuację banku

\begin{tabular}{|l|l|}
\hline \multicolumn{1}{|c|}{$\begin{array}{c}\text { Aktualna pozycja banku na rynku } \\
\text { finansowym }\end{array}$} & \multicolumn{1}{c|}{ Główne cele reklamy } \\
\hline \multirow{3}{*}{ Powstanie banku } & - poinformowanie o powstaniu instytucji \\
& - wprowadzenie logo banku na rynek \\
& - zapoznanie klientów ze sloganem banku \\
& - przedstawienie oferty instytucji finansowej \\
\hline \multirow{3}{*}{$\begin{array}{l}\text { Wprowadzenie nowego produktu na rynek } \\
\text { finansowy }\end{array}$} & - poinformowanie klientów o nowej usłudze \\
& - przedstawienie ceny produktu \\
& - przekonywanie klientów do określonej nowości \\
Zwiększenie zainteresowania znaną usługą & - pozyskiwanie nowych klientów \\
& - poinformowanie o atrakcyjnych warunkach \\
& - wzmacnianie lojalności \\
& - przyciągnięcie nowych klientów \\
\hline \multirow{5}{*}{ Akcje podejmowane wobec konkurentów } & - wzatwianie zrozumienia usługi \\
\hline \multirow{3}{*}{ Zmiana siedziby } & - akcje promocyjne \\
& - przedstawianie dodatkowych korzyści \\
& - innowacyjność \\
\hline & - informacja o nowym adresie \\
& - zwiększanie liczby nowych klientów \\
& - przedstawienie oferty \\
& - zapoznanie nowych klientów z logo i sloganem \\
& banku. \\
\hline
\end{tabular}

Źródło: opracowanie własne na podstawie: Grzywacz [2006: 131]. 
W tab. 1 i tab. 2 ukazana została zależność pomiędzy głównymi celami zastosowania reklamy bankowej a aktualną pozycją banku na rynku finansowym oraz etapem życia produktu bankowego. Warto także podkreślić, że bank tworzący koncepcje strategii marketingowej na najbliższe lata może definiować i zapisywać cele na swój sposób, który będzie wyróżniać spółkę w porównaniu do bezpośrednich konkurentów.

\subsection{Zasady reklamowania usług bankowych}

Funkcjonowanie rynku finansowego w dużej mierze opiera się na wzajemnym zaufaniu pomiędzy jego uczestnikami. Zaufanie to występuje tylko wtedy, gdy zaangażowane podmioty postępują zgodnie z prawem oraz udzielają wiarygodnych informacji dotyczących usług i kontrahentów. Banki o usługach czy też produktach, informują poprzez reklamę, która stanowi element marketingu bankowego i jest podstawowym instrumentem promocji [Wojsznis i Stalończyk 2014: 23].

W celu zadbania o prawidłowe funkcjonowanie sektora bankowego, w tym ochronę interesów konsumentów banków oraz przestrzeganie reguł uczciwego obrotu, Komisja Nadzoru Finansowego określiła ogólny zbiór zasad dotyczących działań reklamowych w tym sektorze [Załacznik do uchwaty KNF z dnia 2 października 2008 r., dostęp: 03.01.2018]. Zgodnie z tymi zasadami przekaz reklamowy powinien cechować się rzetelnością w rozgłaszaniu informacji, dbałością o interesy klientów banków oraz poszanowaniem powszechnie obowiązujących przepisów prawa. Ponadto nie może wprowadzać w błąd ani stwarzać możliwości wprowadzania w błąd. Dotyczy to głównie kwestii takich, jak: tożsamość podmiotu oferującego usługę, istotne cechy reklamowanej usługi, możliwe korzyści, jakie dzięki niej można osiągnąć, a także koszty, czas, zasięg i charakter prawny reklamowanej usługi. Co więcej, sam przekaz nie może odwoływać się do nieprawdziwych bądź nieudokumentowanych danych i informacji oraz nakłaniać do korzystania z reklamowanych usług w sposób niekorzystny dla klienta. W związku z tym, w przekazie reklamowym konieczne jest umieszczenie informacji o potencjalnym ryzyku związanym z reklamowanym produktem finansowym, a w przypadku ofert specjalnych i promocji powinien zawierać dokładne daty ich obowiązywania. Odwoływanie się do wyników badań statystycznych, sondaży, rankingów czy też ratingów powinno skutkować wskazaniem konkretnych źródeł, z których pochodzą. Forma przekazu reklamowego nie może sprawiać wrażenia, że jest informacją neutralną, a jego forma powinna umożliwić odbiorcy swobodne zapoznanie się ze wszystkimi jego elementami. Treści składające się na przekaz reklamowy, uwzględniając charakterystykę grupy docelowej powinny być sformułowane w sposób zrozumiały dla przeciętnego odbiorcy. Ważne jest również wskazanie na istnienie opłat i prowizji, 
a także podanie miejsca, w którym dostępny jest szczegółowy regulamin oferty. Przekaz reklamowy nie może przedstawiać w złym świetle innych podmiotów działających na rynku finansowym [Załacznik do uchwały $K N F \quad z$ dnia 2 października 2008 r., dostęp: 03.01.2018]. Dla poszczególnych produktów finansowych skonstruowane zostały również szczegółowe reguły określające elementy dodatkowe, których wymienienie w przekazie reklamowym jest niezbędne dla pełnej realizacji wcześniej wspomnianych założeń [Kacprzak 2012: 132].

\subsection{Prawne uwarunkowania marketingu w sektorze bankowym}

Szybko rozwijająca się reklama może doprowadzić do nieetycznych postępowań lub też nieodpowiednich zachowań instytucji wobec potencjalnych klientów. By zapobiec rozpowszechnianiu się tych negatywnych skutków zastosowań promocji pojawiło się wiele regulacji wpływających na to, co musi się zawierać lub też czego nie powinno się zamieszczać w reklamach publicznych. Pierwszym i najważniejszym elementem jest wykorzystanie w reklamach wyrazów „bank” oraz „kasa”. Zgodnie z przepisami Prawa Bankowego każda osoba, która zastosuje w swoich promocjach powyższe sformułowania, by czerpać korzyści materialne, nie będąc przy tym bankiem podlega karze grzywny. W przypadku osób, które bez zezwolenia będą prowadzić lub promować działalność, polegającą na gromadzeniu środków pieniężnych innych ludzi w celu udzielania kredytów lub pożyczek może zostać zmuszona do zapłacenia kary w wysokości do 10000000 złotych oraz podlegać będzie sankcji pozbawienia wolności do lat pięciu [Ustawa z dnia 29 sierpnia 1997 r..., art. 171, Dz.U. 2017, poz. 1876, ze zm.].

Jedną $\mathrm{z}$ najnowszych zmian $\mathrm{w}$ przepisie jest obowiązek poinformowania klienta o stopie oprocentowania kredytu, wyodrębnienie opłat uwzględnianych w całkowitym koszcie kredytu, podanie całkowitej kwoty kredytu oraz rzeczywistej rocznej stopy oprocentowania. Zmiany te zostały wprowadzone 22 października 2017 roku i to właśnie wtedy, po raz kolejny ustawodawca ograniczył fantazje i obietnice banków [Kośka, 20.10.2017, dostęp: 03.01.2018].

Kolejny aspekt prawny związany jest z systemem gwarantowania depozytów. Według przepisów prawa informacja o uczestnictwie w danym systemie nie może zostać wykorzystana w celach reklamowych [Ustawa z dnia 29 sierpnia 1997 r..., art. 40, Dz.U. 2017 poz. 1876, ze zm.].

Żadna z reklam nie może także naruszać godności ludzkiej, zawierać treści, które dyskryminują człowieka ze względu na płeć, rasę lub narodowość, ranić przekonań politycznych oraz religijnych, zagrażać rozwojowi psychicznemu, fizycznemu lub moralnemu nieletnich oraz sprzyjać zachowaniom zagrażającym zdrowiu, bezpieczeństwu i ochronie środowiska [Ustawa z dnia 29 grudnia 1992 r..., art. 16, Dz.U. 2017 poz. 1414, ze zm.]. Zakazane przepisami prawa 
zostało także wykorzystanie kryptoreklamy, czyli tworzenie wrażenia całkowicie obiektywnego przekazu, który nie ma charakteru ściśle promocyjnego [Ustawa z dnia 26 stycznia 1984 r..., art. 12, Dz.U. 2017, poz. 2173, ze zm.].

Ostatnim dokumentem, w którym znajdziemy odwołania do reklamy bankowej jest Kodeks Etyki Bankowej. W rozdziale pierwszym dotyczącym relacji banku z klientami zawarto zobowiązanie banków do informowania użytkowników usług o rodzajach i warunkach wykonywanych świadczeń, różnic pomiędzy poszczególnymi ofertami, a także korzyści i ryzyka związanego z poszczególnymi produktami [Kodeks Etyki Bankowej, 2013: 4].

\subsection{Treści reklam produktów bankowych}

Banki prezentując określony produkt finansowy korzystają z odwołania do tradycji lub do współczesności. Wybór określonego rodzaju przekazu reklamowego oddziałuje na wizerunek danej instytucji. Aktualnie wiele z nich korzysta z obu tych rozwiązań w zależności od tego, do jakiej grupy docelowej jest skierowany dany produkt. Dzieje się tak ze względu na szeroki wachlarz oferowanych usług, które mają spełniać potrzeby różnych klientów [Kacprzak 2012: 134].

Dekadę temu, większość banków promowała swoje produkty w sposób tradycyjny, ukazując przy tym swoją działalność jako stabilną, godną polecenia i zaufania, która zadba o oszczędności klienta. Reklama ta spełniała określone założenia i przynosiła pozytywny efekt dla banków. Jednak do utraty zaufania społecznego przyczynił się kryzys finansowy, który zraził ludzi do korzystania z usług bankowych, a także wzbudził w nich niepewność i niechęć do owych instytucji [Kacprzak 2012]. Niektóre banki w dalszym ciągu, konsekwentnie budują wizerunek swojej marki bazując na długoletnim doświadczeniu, tak jak robi to Nest Bank funkcjonujący niegdyś jako FM Bank SA. W reklamach można zaobserwować wyraźne zaakcentowanie wartości rodzinnych, co ukazuje rys. 1.

Przykład ten należy do niewielkiej części reklam, które opierają się na tradycji, bowiem w dzisiejszych czasach banki skupiają się na zerwaniu ze standardowym niegdyś podejściem do klienta. W sektorze bankowym zaobserwować można wszechobecność nowoczesnych rozwiązań z zakresu technologii, ze szczególnym dbaniem o zaspakajanie potrzeb i komfortu konsumentów. W związku z tym, w ofertach reklamowych pojawiają się zwroty typu: „sam ustalasz wysokość raty” czy „kredyt na miarę twoich potrzeb”. Dzięki temu klient ma wrażenie, że produkt, który wybrał, odpowiada jego potrzebom, co nie odpowiada stanowi faktycznemu. Rozważając sformułowanie „sam ustalasz wysokość raty”, klient może być usatysfakcjonowany z faktu, iż co miesiąc spłaca stosunkowo niską ratę, jednak powoduje to także znaczne wydłużenie się okresu kredytowania, co w efekcie powoduje, że całkowity koszt kredytu rów- 
nież jest zdecydowanie wyższy [Kacprzak 2012: 135]. W reklamach pojawia się mnóstwo tego typu metod zwanych potocznie „gwiazdkami” czy „haczykami”, które czynią ofertę atrakcyjną, mimo że do tej kategorii, z punktu widzenia klienta, nie należą.

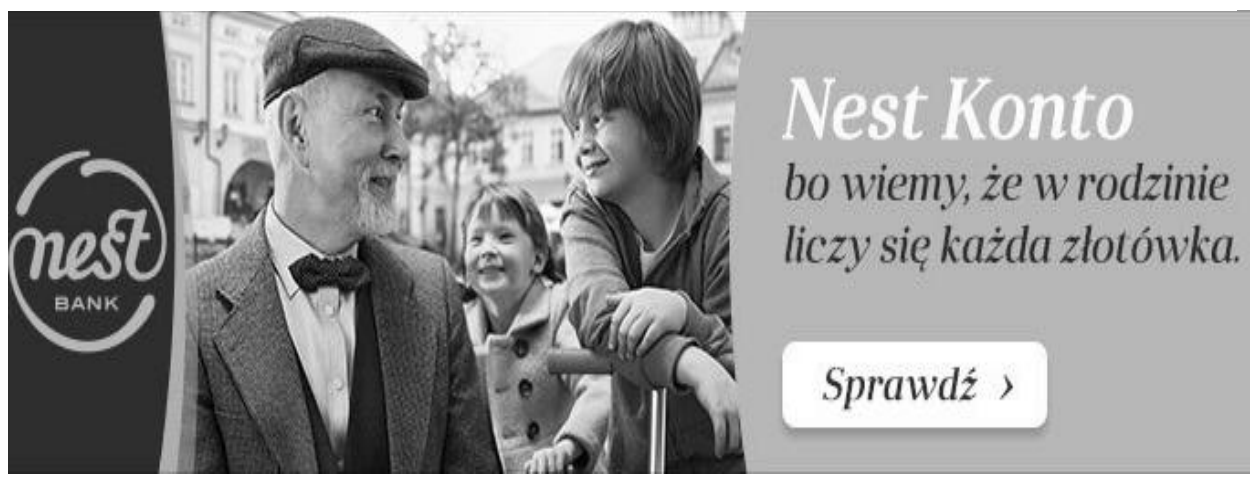

Rysunek 1. Wycinek oferty Nest Banku S.A.

Źródło: www 1 [dostęp: 03.01.2018].

Ważnym aspektem $\mathrm{w}$ prezentowanych przez instytucje finansowe reklamach jest dobór podmiotu, który promuje dany produkt. Można wyróżnić kilka rodzajów postaci, które odgrywają rolę swoistego promotora [Kacprzak 2012: 135]: sławne osoby ze świata showbiznesu (celebryci), specjaliści z dziedziny finansów, zadowoleni z usługi użytkownicy, spersonifikowane przedmioty lub zwierzęta, a także postacie wymyślone na potrzeby reklamy.

Dobór persony do promocji danego produktu jest kluczowym elementem, który wpływa na wizerunek danej marki. Celem każdego banku jest wyróżnienie się na szeroko rozbudowanym rynku świadczonych usług finansowych, dlatego coraz śmielej wykorzystują w swoich reklamach postacie abstrakcyjne, które ze względu na swoją unikalność zapadają w pamięci klientów [Woźniczka 2011: 14-17 [za:] Kacprzak 2012: 135]. Ostatnimi czasy w spotach reklamowych występują sławne osobistości takie jak: zasłużeni sportowcy czy aktorzy. Sprawia to, że konkretny komunikat reklamowy staje się znacznie bardziej atrakcyjny dla odbiorcy i zwraca na niego uwagę częściej aniżeli na komunikat, w którym występują eksperci finansowi. Zaangażowanie sławnej osoby grozi jednak utratą wizerunku danej marki, co może być spowodowane niewłaściwym zachowaniem takiej osoby w przestrzeni publicznej [Kacprzak 2012: 137]. 


\subsection{Wybrane przekazy marketingowe}

Ze względu na dużą konkurencję i powielenie produktów, które występuje w sektorze bankowym, banki „walczą” o klienta stosując różnego rodzaju techniki marketingowe $\mathrm{w}$ reklamach.

W 2016 roku bank BZ WBK S.A. zorganizował kampanię reklamową, która wspierała polską drużynę na Mistrzostwach Europy w piłce nożnej. Zjednoczenie polskich kibiców było kluczowe w całym przedsięwzięciu. Dzięki temu klienci - widzowie nabrali większego przekonania i sympatii do Banku Zachodniego, który okazał się być przyjazny i otwarty dla każdego. Działalność ta wpłynęła korzystnie na cele sprzedażowe banku. Ponadto instytucja ta stała się ikoną w sektorze reklam bankowych, ze względu na wykorzystanie potencjału, tak ważnego w Polsce wydarzenia sportowego.

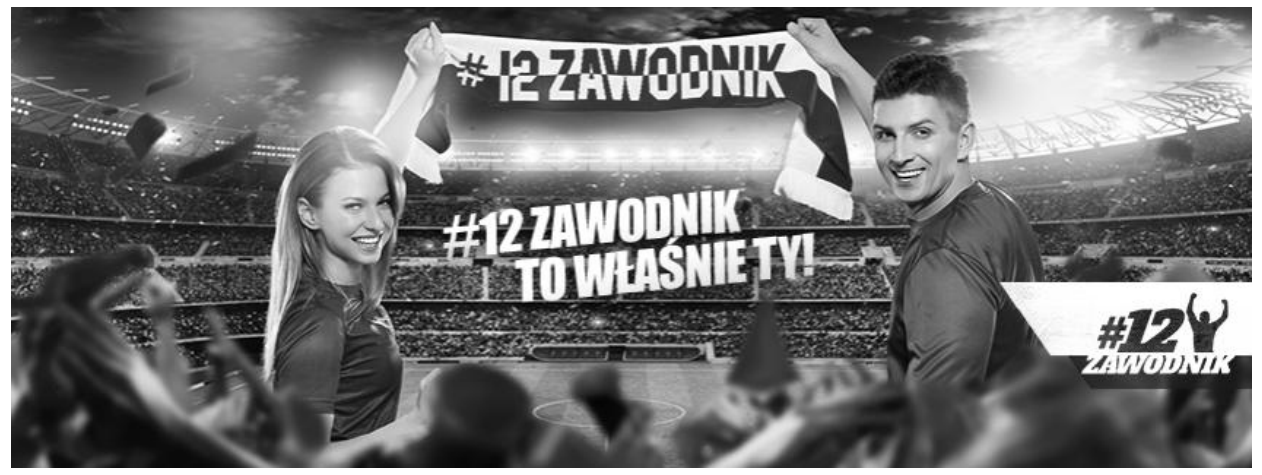

Rysunek 2. Wycinek promujący akcję \#12 zawodnik

Źródło: www2 [dostęp: 03.01.2018].

BGŻ BNP Paribas S.A. może pochwalić się kampanią „Wszystko gra”, zachęcającą do uruchomienia na rachunku osobistym kredytu gotówkowego, którego środki mogą być przeznaczone na dzieci i ich potrzeby. W reklamie banku pojawia się komizm słowny i sytuacyjny, który nadaje przyjemny charakter całej promocji produktu. BGŻ dzięki takiej działalności osiągnął przychylność rodzin, naświetlając rodzicom, w łagodny sposób, problem braku zainteresowania potrzebami najbliższych. Ponadto instytucja ta wychodzi naprzeciw gospodarstwom domowym, wykazując troskę o domowy budżet, który nie tylko powinien zaspokajać wydatki na życie codzienne, ale także wydatki na plany swojej rodziny będącej najważniejszą wartością w życiu [opracowano na podstawie oficjalnej strony banku BGŻ BNP Paribas S.A., dostęp: 05.01.2018]. 


\section{MARKETING BANKOWY W UJĘCIU EMPIRYCZNYM}

Autorzy, wykorzystując metody oparte na studiach przypadków podejmują próbę realizacji postawionego na wstępie celu. Prezentacja grup docelowych, przegląd sprawozdań finansowych banków oraz analiza ich współczesnego środowiska marketingowego umożliwiają udzielenie odpowiedzi na pytanie badawcze. Wszelkie wnioski będące wynikiem badań własnych poparte zostały odpowiednimi ilustracjami oraz danymi numerycznymi.

\subsection{Kanały i narzędzia reklamowania produktów finansowych}

Strategia rozpowszechniania produktów oferowanych przez banki jest istotnym czynnikiem zwiększania poziomu konkurencyjności w sektorze bankowym. W ostatnich latach można zaobserwować powszechną digitalizację świadczonych usług finansowych, jak i metod ich dystrybucji wśród konsumentów [Goska 2014: 23]. Kanały, za pośrednictwem których reklamowane są produkty oferowane przez banki to wszelkiego typu media: Internet, telewizja, radio, prasa, banery, ulotki, reklama mobilna.

Dużą popularnością wśród klientów cieszy się popularyzacja produktów za pomocą Internetu. Klienci stają się coraz bardziej wymagający i domagają się wprowadzenia innowacyjnych rozwiązań przez podmioty usługowe, dlatego też instytucje te wydają ogromne nakłady pieniężne na marketing prowadzony w „sieci”. Banki wysyłają powiadomienia na telefony i smartfony za pomocą swojej aplikacji bądź bezpośrednio w formie wiadomości tekstowej, w celu zaanonsowania konkretnego produktu bądź usługi. Rozwój kampanii reklamowych jest szczególnie widoczny w portalach społecznościowych takich jak Facebook, Instagram czy YouTube, co przedstawiono na rys. 3-5.

Mimo spadku znaczenia telewizji jako nośnika promocji produktów, wciąż odgrywa ona znaczącą rolę. Banki swoje spoty reklamowe konstruują często wykorzystując żarty słowne i znane osobistości ze świata show-biznesu. Takie zastosowanie można zaobserwować w spocie reklamowym banku PKO BP S.A. z Szymonem Majewskim w roli głównej.

Tak jak w reklamie telewizyjnej, tak i w radiu podejście do prezentacji danego produktu finansowego jest podobne. W kanale tym często wykorzystuje się sławną personę, która poleca dany produkt i gwarantuje zadowolenie klienta. $\mathrm{W}$ prasie o dowolnej tematyce można napotkać co najmniej kilka ofert pożyczkowych. Często także praktykuje się sponsorowanie artykułów w postaci profesjonalnej publikacji zawierającej grafikę bądź logotyp, który promuje daną markę [Strona internetowa o tematyce $\mathrm{z}$ zakresu marketingu prowadzona przez firmę Mayko.pl, dostęp: 02.01.2018]. 


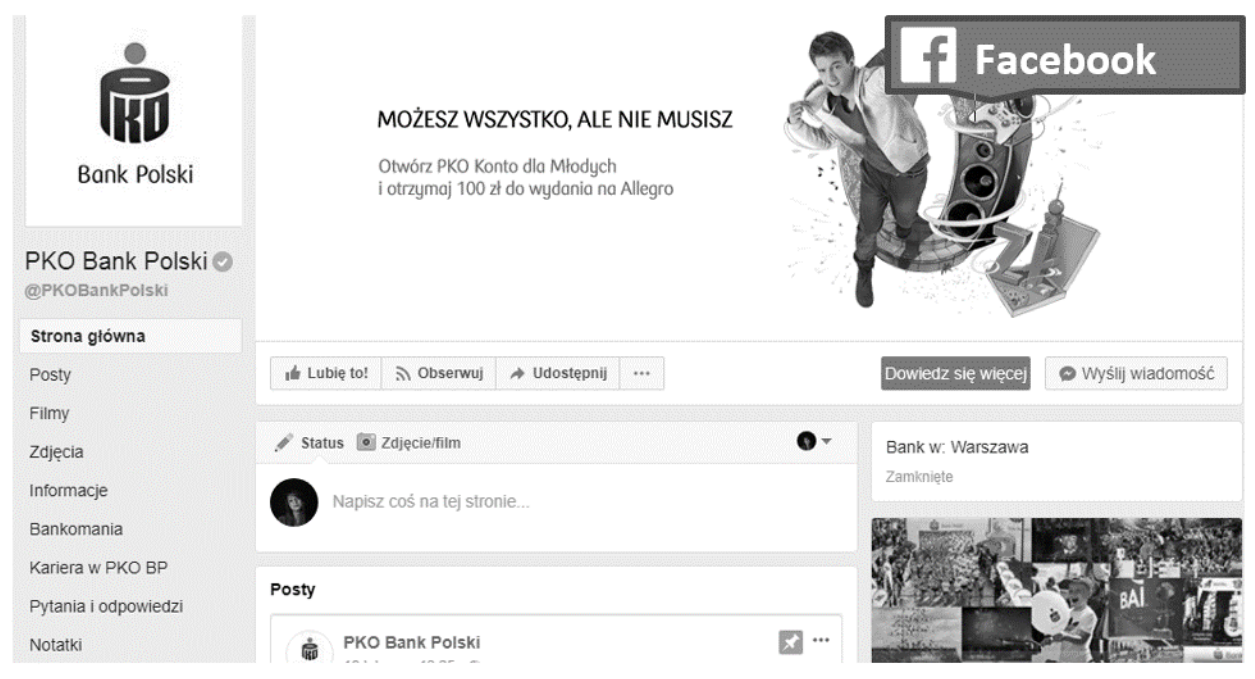

Rysunek 3. Fragment oficjalnej strony banku PKO BP S.A. na Facebook'u

Źródło: www3 [dostęp: 23.02.2018].
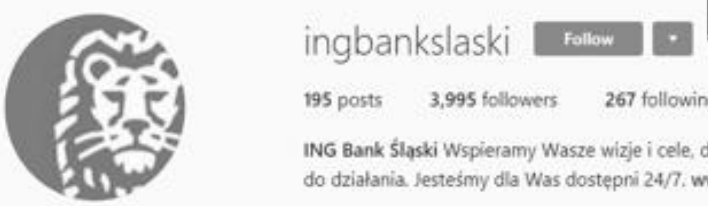

\section{Instagram}

195 posts $\quad 3,995$ followers $\quad 267$ following

ING Bank Śląski Wspieramy Wasze wizje i cele, duze i małe, inspirujemy i motywujemy do działania. Jestesmy dla Was dostępni 24/7. www.ingbank.pl/weekending
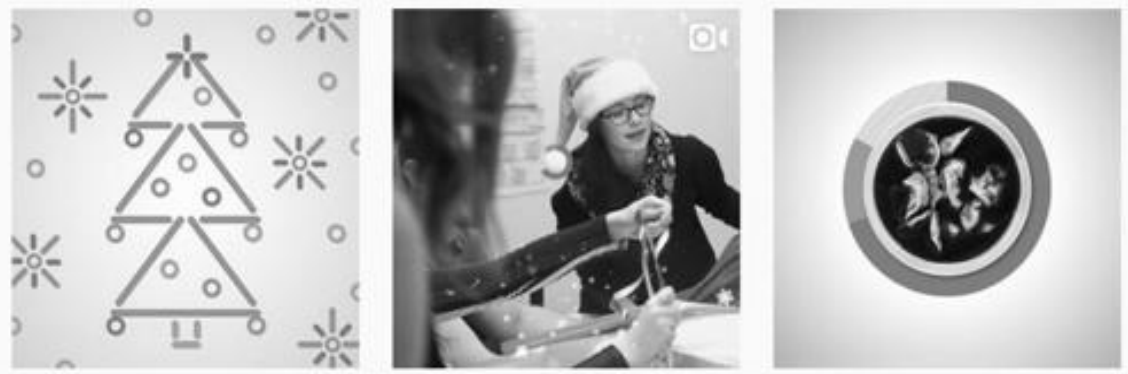

Rysunek 4. Fragment oficjalnej strony banku ING Banku Śląskiego S.A. na Instagramie

Źródło: www4 [dostęp: 03.01.2018]. 


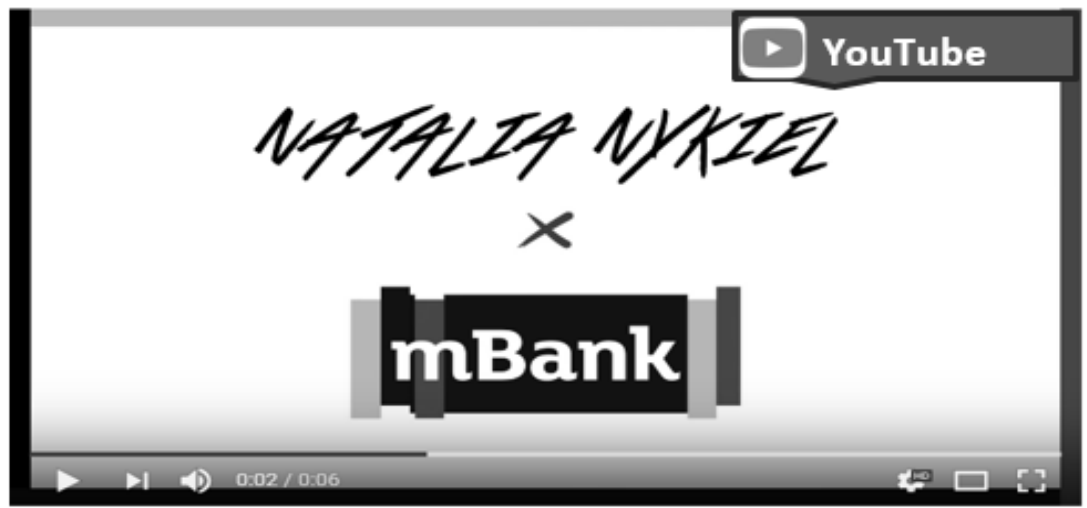

mBank i Natalia Nykiel

410 wyświetleń

$14 \mathrm{ql}_{2} \rightarrow$ UDOSTEPNIJ $\equiv_{+} \ldots$

Tำ mBankTV

SURSKRYRU, 7 TYS

Rysunek 5. Kadr z reklamy mBanku S.A. na YouTube

Źródło: www5 [dostęp: 03.01.2018].

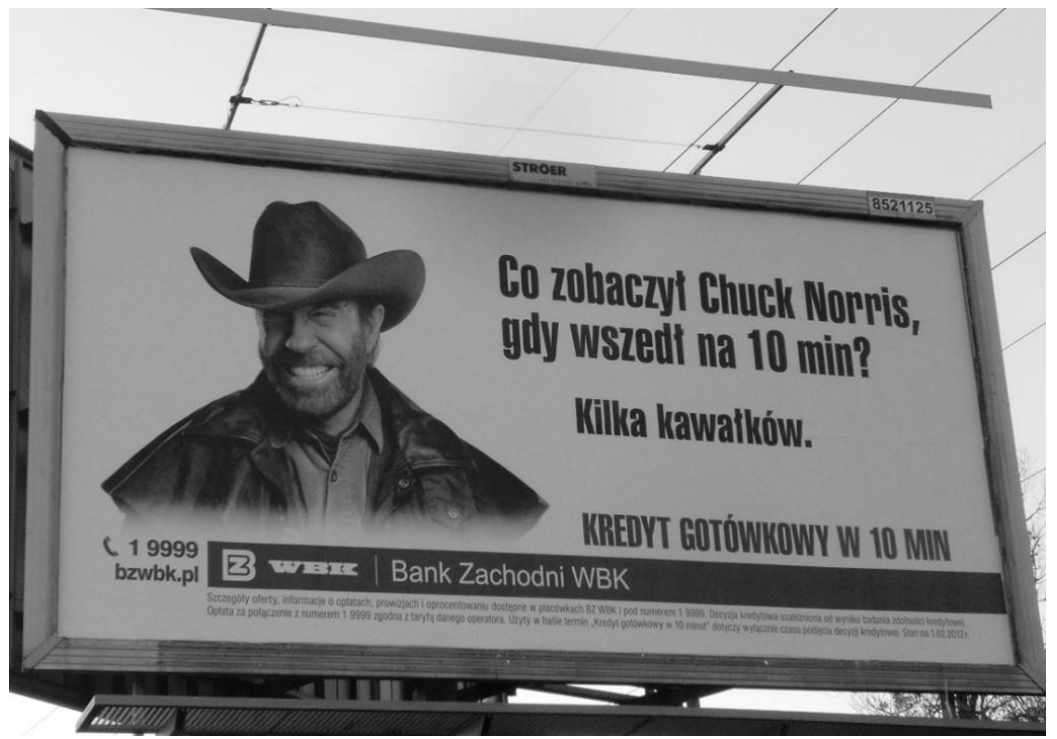

Rysunek 6. Bilboard banku BZ WBK S.A.

Źródło: www6 [dostęp: 23.02.2018]. 
Mimo niskiego poziomu zainteresowania konsumentów broszurami czy bilbordami są one nadal powszechne. Tego typu rodzaj reklamy zwany inaczej outdoor można obserwować w miejscach publicznych, gdzie w ciągu dnia występuje duża rotacja osób. Takimi miejscami są np.: przystanki autobusowe, wysokie budynki w centrum miast, komunikacja miejska itp. Rysunek 6 przedstawia przykład reklamy znajdującej się w przestrzeni publicznej.

\subsection{Grupy docelowe marketingu bankowego}

Banki docierają do swoich klientów poprzez reklamę, która spełnia funkcję informacyjną oraz zachęcającą i nakłaniającą do pewnego działania. Celem reklamy jest zbliżenie klienta do produktu. Nośnikami reklamy są m.in. telewizja, radio, ogłoszenia, ulotki itp. Dobór odpowiedniego przekazu reklamowego, nośników oraz czasu trwania akcji reklamowej uzależniony jest od rodzaju, charakteru oraz grupy docelowej [Borawska 2009: 164].

W literaturze wyróżnia się podział klientów na dwie podstawowe grupy: klientów indywidualnych oraz instytucjonalnych. W rozróżnieniu na te grupy, banki opracowują różne produkty oraz świadczą odmienne usługi. Przy przygotowywaniu ofert produktowych, odpowiadających potrzebom klientów, banki uwzględniają te potrzeby stosując określone kryteria segmentacji [Szulce i in. 2004: 277]. Do głównych kryteriów segmentacji rynku klientów indywidualnych należy wiek, sytuacja finansowa, uwarunkowania psychograficzne, behawioralne czy geograficzne. Natomiast przy kategoryzacji klientów instytucjonalnych, bierze się pod uwagę wielkość sprzedaży, rodzaj prowadzonej działalności oraz postawy wobec usług bankowych [Borawska 2009: 169].

Wykorzystując segmentację rynku, banki tworzą przekazy reklamowe w taki sposób, aby trafić do grupy odbiorców danego produktu. Dla przykładu, biorąc pod uwagę wiek docelowych klientów, reklamy skierowane do osób starszych różnią się od tych, które mają zwrócić uwagę młodszego pokolenia. Dla pierwszej z tych grup w przekazie reklamowym wykorzystuje się komunikację dotyczącą stabilnej przyszłości, lepszego jutra, czy też stałej kwoty raty. Kanałami dystrybucji reklam są tu przeważnie: telewizja, radio, gazety, ulotki. Inaczej natomiast jest w przypadku młodszych klientów. Do tej grupy odbiorców najlepiej trafia przekaz odnośnie realizacji marzeń czy elastyczności w terminach spłaty zobowiązań, umieszczony głównie w Internecie [Kacprzak 2012: 135]. Ważną rolę w przekazie reklamowym dla tej grupy odgrywa także wykorzystanie w nim nowości technologicznych. Co więcej, przekaz reklamowy jest ciekawszy dla młodych odbiorców, kiedy dany produkt reklamowany jest przez znaną osobę. Taki chwyt marketingowy wykorzystał w swojej kampanii reklamowej jeden z polskich banków - PKO BP S.A. 
Kampania pod hasłem „Dużo dobrego za zero” reklamuje PKO Konto dla Młodych z udziałem Martina Stankiewicza, jednego z polskich vlogerów. Za otwarcie reklamowanego konta można uzyskać 2-osobowe zaproszenie do restauracji podczas trwania Festiwalu Restaurant Week oraz do $50 \mathrm{zł}$ zwrotu co miesiąc, przez pół roku za dokonanie płatności kartą w placówkach gastronomicznych. Grupą docelową kampanii są osoby w wieku 18-26 lat. Filmy promocyjne emitowane są m.in. na YouTube, playerze TVP oraz w mediach społecznościowych. Jak podkreśla Marek Kozłowski, dyrektor Biura Komunikacji Marketingowej w PKO Banku Polskim ,filmy z udziałem Martina Stankiewicza cieszą się ogromną popularnością, a kampania skrojona na miarę kampanii internetowej, $\mathrm{z}$ dopasowanymi do grupy docelowej formatami reklamowymi i odpowiednim kontekstem to klucz do sukcesu" [Tomczak 22.08.2017, dostęp: 04.01.2018].

\subsection{Wydatki na marketing oraz ich efekty}

Motywacją do podjęcia analizy sprawozdań finansowych badanych banków (Alior Banku S.A., ING Banku Śląskiego S.A, mBanku S.A. oraz Banku Zachodniego WBK S.A.) była rola tych instytucji w przekazach marketingowych kierowanych poprzez różne kanały komunikacji także do klientów młodych. Zaangażowanie przejawiane przez te instytucje finansowe, aby pozyskać klientów (czasem użytkowników już od 13 roku życia) jest zauważalne w środowisku marketingowym. Dokonując przeglądu sprawozdań finansowych badanych banków w Polsce w okresie 2014-2016 możemy określić poziom ich wydatków marketingowych, co przedstawia tab. 3 .

Tabela 3. Wydatki marketingowe banków w latach 2014-2016 (w mln zł)

\begin{tabular}{|c|c|c|c|}
\hline Wyszczególnienie & 2014 & 2015 & 2016 \\
\hline Alior Bank S.A. & 38,5 & 52,5 & 56,8 \\
\hline Bank Zachodni WBK S.A & 119,1 & 187,84 & 146,59 \\
\hline ING Bank Śląski S.A. & 109,7 & 117,1 & 95,0 \\
\hline mBank S.A. & 126,2 & 117,6 & 115,6 \\
\hline
\end{tabular}

Źródło: opracowanie własne na podstawie skonsolidowanych sprawozdań finansowych Alior Banku S.A., Banku Zachodniego WBK S.A., ING Banku Śląskiego S.A., mBanku S.A. z lat 2014-2016.

Na podstawie informacji zawartych w tab. 3 możemy zaobserwować, że Bank Zachodni WBK S.A., w porównaniu do swoich najsilniejszych konkurentów na rynku finansowym, wydał największą kwotę pieniędzy na działania mar- 
ketingowe w latach 2014-2016. Kwota ta w 2016 roku jest jednak mniejsza o $22 \%$ w porównaniu do roku 2015. Uważamy, że zmiana jest spowodowana rotacjami wśród aktorów i sławnych osób, z którymi bank współpracował. W okresie 2014 oraz 2015, BZ WBK S.A. mógł poszczycić się współpracą z Kevinem Spacey, co mogło znacząco podnosić wydatki marketingowe.

Najmniejsze koszty związane z marketingiem i promocją w latach 2014 -2016 ponosił Alior Bank S.A., jednak zauważalny jest wzrost udziału tych wydatków w okresie badanych lat. Zgodnie z trendami rynkowymi - zwłaszcza instytucje finansowe muszą racjonalnie gospodarować swoimi przychodami uzyskiwanymi na działalności bankowej. Trzeci największy bank według wartości aktywów w Polsce - BZ WBK S.A. może przeznaczać znacznie większą kwotę pieniężną na strategie marketingowe w porównaniu do Alior Banku S.A., który zajmuje aktualnie 10. miejsce w rankingu według wartości aktywów [Bereziński, dostęp: 03.01.2017].

Tabela 4. Liczba rachunków oszczędnościowo-rozliczeniowych i tempo ich zmian w bankach w latach 2014-2016

\begin{tabular}{|l|c|c|c|c|c|}
\hline \multirow{2}{*}{ Wyszczególnienie } & \multicolumn{2}{|c|}{$\begin{array}{c}\text { Liczba wszystkich RORów w wybranych } \\
\text { bankach w Polsce }\end{array}$} & \multicolumn{2}{c|}{ Tempo zmian } \\
\cline { 2 - 6 } & IV kw. 2014 & IV kw. 2015 & IV kw. 2016 & $2014 / 2015$ & 2015/2016 \\
\hline Alior Bank S.A. & 1312800 & 1433695 & 1944299 & $9,21 \%$ & $35,61 \%$ \\
\hline Bank Zachodni WBK S.A & 2911942 & 2980000 & 3120000 & $2,34 \%$ & $4,70 \%$ \\
\hline ING Bank Śląski S.A. & 2265000 & 2497000 & 2689000 & $10,24 \%$ & $7,69 \%$ \\
\hline mBank S.A. & 2882631 & 3024486 & 3214253 & $4,92 \%$ & $6,27 \%$ \\
\hline
\end{tabular}

Źródło: opracowanie własne na podstawie raportów strony internetowej Bankier.pl - Polska bankowość w liczbach - z lat 2014-2016.

Tabela 5. Zyski netto uzyskiwane przez instytucje finansowe w latach 2014-2016 (w tys. zł)

\begin{tabular}{|c|c|c|c|}
\hline Wyszczególnienie & 2014 & 2015 & 2016 \\
\hline Alior Bank S.A. & 337030 & 311415 & 632075 \\
\hline Bank Zachodni WBK S.A & 1994632 & 1756210 & 2081720 \\
\hline ING Bank Śląski S.A. & 1067900 & 1140000 & 1208700 \\
\hline mBank S.A. & 1174096 & 1301233 & 1219339 \\
\hline
\end{tabular}

Źródło: opracowanie własne na podstawie skonsolidowanych sprawozdań finansowych Alior Banku S.A., Banku Zachodniego WBK S.A., ING Banku Śląskiego S.A., mBanku S.A. z lat 2014-2016. 
Marketing oraz finanse to ściśle powiązane ze sobą elementy przedsiębiorstw. Dzięki przeprowadzaniu dokładnych analiz finansowych możliwe jest podejmowanie odpowiednich działań pozwalających spółkom tworzyć przewagę konkurencyjną i osiągać założone cele.

Banki konkurują ze sobą poprzez wdrażanie coraz to nowszych pomysłów na reklamę. Niektóre wciąż współpracują z rozgłośniami radiowymi oraz prasą, inne natomiast próbują swoich sił na stronach internetowych, takich jak YouTube, Facebook oraz rozwijają swoją działalność wykorzystując reklamy telewizyjne. Informacje zamieszczone w tab. 4 oraz tab. 5 pozwalają stwierdzić, że działania marketingowe prowadzą do stałego wzrostu liczby otwieranych kont bankowych oraz pozwalają zwiększać lub utrzymywać na stabilnym poziomie zysk wypracowywany przez badane banki.

\section{PODSUMOWANIE}

$\mathrm{Na}$ podstawie rozważań przedstawionych $\mathrm{w}$ niniejszym artykule można zauważyć, że reklama produktów i usług bankowych jest istotnym elementem strategii marketingowej, służącym komunikowaniu się banku z klientem. Do głównych celów reklamy zalicza się: informowanie klientów o produkcie, nakłanianie do zakupu oraz przypominanie o istnieniu i możliwości nabycia produktu. Cele te uzależnione są od cyklu życia produktu oraz aktualnej pozycji banku na rynku. Przy tworzeniu strategii marketingowej banki definiują odmienne cele, co wyróżnia je od swoich konkurentów. Mając na uwadze przedstawione w pracy zasady konstruowania reklam bankowych, można stwierdzić, że nie różnią się one znacznie od przekazów o charakterze komercyjnym. Tworząc reklamę odnośnie usług finansowych ważna jest znajomość przepisów prawa, mających na celu ochronę interesów konsumentów oraz przeciwdziałanie nieuczciwej konkurencji. Dobór mediów do reklam tego typu w dużej mierze zależy od grupy odbiorców, do których przekaz jest kierowany. Najczęściej wykorzystuje się tu telewizję, Internet, radio oraz prasę. W celu wzmocnienia przekazu, banki do promowania swojego produktu, wykorzystują znane postaci, dzięki którym reklamowany produkt staje się bardziej atrakcyjny dla potencjalnego klienta.

Biorąc pod uwagę zawarte $\mathrm{w}$ pracy rozważania oraz dane liczbowe o sytuacji finansowej wybranych banków można stwierdzić, że wydatki na cele marketingowe mają isotny wpływ na wartość zysku netto tych instytucji. Dzięki reklamom klienci są bardziej skłonni do zakupu oferowanych usług bądź produktów, co przekłada się na wielkość zysku omawianych podmiotów. Przedstawione w opracowaniu przykłady przekazów reklamowych pokazują, że banki rywalizują między sobą o pozyskanie nowych grup odbiorców, dlatego 
przykładają dużo uwagi do tworzenia ofert swoich produktów. Wykorzystując różne techniki marketingowe starają się w jak najlepszy sposób dotrzeć do klientów i przekonać ich, że zakup reklamowanego produktu w danym banku jest korzystniejszy od oferty prezentowanej przez konkurencyjne instytucje.

\section{BIBLIOGRAFIA}

Bereziński J., 10 największych banków w Polsce. Ranking wedtug wartości aktywów, strona internetowa Money.pl, https://www.money.pl/gospodarka/wiadomosci/artykul/10-najwiekszychbankow-w-polsce-ranking, 142,0,2335630.html [dostęp 03.01.2017].

Borawska A., 2009, Zastosowanie marketingu mix w bankowości, „Roczniki Ekonomii i Zarządzania", nr 1(37).

Goska S., 2014, Nowoczesne kanały dystrybucji produktów bankowych - porównanie ofert wybranych banków, „Finanse i Prawo Finansowe”, nr 1/2.

Grzywacz J., 2006, Marketing $w$ działalności banku, Difin, Warszawa.

Kacprzak M., 2012, Specyfika reklamy ustug sektora bankowego w Polsce, [w:] A. Kozłowska (red.) Strategie komunikacji reklamowej z konsumentem, Wyższa Szkoła Promocji, Warszawa.

Kodeks Etyki Bankowej, 2013, Związek Banków Polskich, Warszawa.

Kośka M., Rewolucja w reklamach banków. Mały druk odchodzi w przeszłość, 20.10.2017, strona internetowa Money.pl, https://www.money.pl/gospodarka/wiadomosci/artykul/banki-rekla ma-zmiany-w-przepisach-rrso,235,0,2379499.html [dostęp: 03.01.2018].

Mazurek-Łopacińska K., 1997, Zachowania nabywców jako podstawa strategii marketingowej, Wydawnictwo Akademii Ekonomicznej im. Oskara Langego, Wrocław.

Oficjalna strona banku BGŻ BNP Paribas S.A., www.bgzbnpparibas.pl/repozytorium/klienciindywidualni/kredyt-gotowkowy-wszystko-gra [dostęp: 05.01.2018].

Strona internetowa o tematyce $z$ zakresu marketingu prowadzona przez firme Mayko.pl, https://marketingwsieci.pl/slownik-e-marketingu/artykul-sponsorowany/ [dostęp: 02.01.2018].

Szulce H., Florek M., Walkowiak K., 2004, Segmentacja jako podstawa zróżnicowania działań marketingowych, „Acta Universitatis Lodziensiss. Folia Historica”, nr 179.

Tomczak K., Dużo dobrego za zero - nowa kampania Konta dla Młodych w PKPO Banku Polskim, 22.08.2017, strona internetowa bankomania.pkobp.pl, https://bankomania.pkobp.pl/zbanku/duzo-dobrego-za-zero-nowa-kampania-konta-dla-mlodych-w-pko-banku-polskim/ [dostęp: 04.01.2018].

Ustawa z dnia 26 stycznia 1984 r. Prawo prasowe, tj. Dz.U. 2017, poz. 2173.

Ustawa z dnia 29 grudnia 1992 r. o radiofonii i telewizji, tj. Dz.U. 2017, poz. 1414.

Ustawa z dnia 29 sierpnia 1997 r. - Prawo bankowe, tj. Dz.U. 2017, poz. 1876.

Witek-Hajduk M., Cykl życia marki produktu, „International Journal of Management and Economics", nr 27 [dostęp: 03.01.2018].

Wojsznis B., Stalończyk I., 2014, Etyczne aspekty działalności marketingowej banków jako element strategii CSR, „Przegląd Organizacji”, $\mathrm{nr} 8$.

Woźniczka J., 2011,, Wykorzystanie tzw. zwyklych ludzi i znanych postaci w kreacji reklamowej a efekty komunikacyjne reklamy, „Marketing i Rynek”, nr 10.

[www1] www.nestbank.pl [dostęp: 03.01.2018].

[www2] www.blog.bzwbk.pl [dostęp: 03.01.2018].

[www3] https://www.facebook.com/PKOBankPolski [dostęp: 23.02.2018].

[www4] www.instagram.com/ingbankslaski [dostęp: 03.01.2018]. 
[www5] www.youtube.com/user/mBankTV [dostęp: 03.01.2018].

[www6] www.adbuzzer.wordpress.com [dostęp: 23.02.2018].

Załacznik do uchwaty KNF z dnia 2 października 2008 r., https://www.knf.gov.pl/knf/pl/kompo nenty/img/KNF_reklamy_bankowe_2_10_08.pdf [dostęp: 03.01.2018].

Zespół wfirma.pl, Marketing bankowy - historia rozwoju, 09.06.2017, strona internetowa Poradnikprzedsiebiorcy.pl, https://poradnikprzedsiebiorcy.pl/-marketing-bankowy-historia-rozwoju, [dostęp: 30.12.2017].

\title{
BANK ADVERTISING AS AN INSTRUMENT FOR PROMOTIONAL ACTIVITY OF FINANCIAL INSTITUTIONS
}

\begin{abstract}
Demanding customers and wide range of products and services offered by financial institutions make a tough barrier for free entry to the financial market. Offering similar or the same products with new name won't distinguish one organization from competitors, therefore, advertising fulfils an important function. Basing on analysis of chosen by authors banks and marketing activities, the article shows what does the advertising mean and how it influences on banking operations and prospective customers. The article demonstrates also the dependence between marketing spendings and actual financial situations of organization which was presented on the grounds of individual activities on the interbank market.
\end{abstract}

Keywords: advertising, bank marketing, image, financial institution. 